\title{
A CRIAÇÃO PELO OLHAR
}

\section{REFERÊNCIAS BIBLIOGRÁFICAS}

BRADIEY, A.C. Shakespeareean tragedy: lectures on Hamlet, Othello, King Lear, Mocbeth. London: Macmillon, 1950. BRESSON, Robert (Dir.). The trial of Joon of Arc. Fronģo, 1962.

CATRYSSE, Pattick. Film (odoptotion) os tronslotion. Jorget. v. 4, n. 1, p. 53-70, 1992.

DREYER, Corl (Dir.). Possion of Joon of Arc. Frongso, 1928.

DUARTE, Lélio Mario Porreiro. Ironia, humor e fingimento literório. XXIV SENAPULLI C Compinas, Unicomp, joneiro 1994 GODARD, Jean-Luc. Godord on Godard. In: LEROY, Jeon, MLLNE, Tom (Ed.). Godord on Godord. New York: the Viking Press., 1968. GODARD, Jeon-Luc (Dir.). King Lear. Fronco, 1987.

rik Von. Tronslation and Literory Genre: the European Picoresque Novel in the 17th and 18th centuries. In: Hermons,

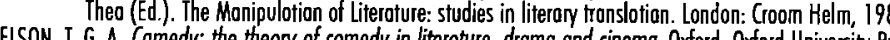

SHCW PREMINGER, Alex (Ed). Princeton Encyclopedio of Poetry ond Poetics. New Jersey: Princeton University Press, 1965.

SHAKESPEARE, Williom, King Leor. London: Methuen, 1961. (Arden edition).

. Rei Lear. In: . Obro completo. Rio de Joneiro: Nova Aguilor, 1989. v. I, p. 621-704.

\section{RESUMO}

Análisis de algunas imágenes cinematográficas y literarias de la actualidad que redimensionan el papel de la mirada demiúrgica e centinela y recuperan al mismo tiempo varios elementos de una tradición cultural heterogénea. 
$\mathrm{Na}$ tela do cinema, após inúmeras tentativas em que desliza no líquido amniótico, o doutor Victor Frankenstein consegue transformar sua recém-nascida criatura em homo erectus. O filme de Kenneth Branagh, ao retomar a obra romântica de Mary Shelley, reacende uma memória cultural obsedada pelo ato de criar, de fazer nascer, de dar luz.' Desde os relatos histórico-adâmicos até os andróides do século $\mathrm{XX}$, o mundo ocidental vasculha os enigmas de sua origem, devir e finalidade através da narração sistemática de eventos e seres fabulosos.

$\mathrm{Na}$ narrativa cinematográfica, o olhar da câmera oferece ao telespectador experiências como a de Frankenstein que reacendem o desejo mitológico da invenção de outro ser, acontecimento que desencadeia um estado conflituoso entre criador e criatura. As rebeliões provocadas por esses filhos produzidos artificialmente — sejam eles máquinas, monstros ou andróides - recordam os conflitos existentes nas relações pai/filho e também entre a divindade primordial e o ser criado que com ela estabelece mecanismos paradoxais de desafio e identidade, como no caso da expulsão do Éden.

É assim que, em Blade Runner, o líder dos andróides chama de "pai" ao cientista que os criara e, após executá-lo, estimula uma luta de resistência para garantir a continuidade da vida dos replicantes. Já em Sonhos, de Akira Kurosawa, o demônio chorão atribui à comunidade científica a paternidade de forças incontroláveis: o cenário pós-atômico, as mutações dos seres vivos e a dor da eternidade falam de um tempo futuro em que os caracteres humanos cedem lugar a criaturas monstruosas e cenas antropofágicas. No filme 2001, uma odisséia no espaço, de Stanley Kubrick, os astronautas destroem sua criatura antes que o computador rebelado lhes faça o mesmo. $\mathrm{Na}$ televisão, uma avalanche de produções japonesas e americanas bombardeia diariamente o público infanto-juvenil com imagens de seres compostos de elementos arcaicos das cavernas e mutantes inter-galácticos, muitas vezes numa guerra solitária e romântica contra seu inventor. $O$ desejo contemporâneo de investigação e descoberta,

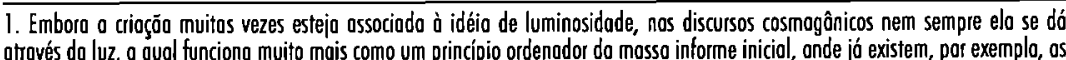
através da luz, o qual funciona muito mais como um princípio ord
trevose e as óguas, paro os cristóos, ou o Coos, no antiga Grécio. ao mover o olhar ocidental para o espaço cósmico, acrescenta ao antigo céu as estranhas luzes de OVNIs e extraterrestres, que ora aparecem como gênios indefesos, ora como destruidores implacáveis dos terráqueos. Entretanto, o indicador luminoso de um ET, que cicatriza o dedo ulcerado da criança, parece relembrar os episódios da Capela Sistina em que o dedo de Deus confere vida a um Adão ainda inocente e dócil.

Muito antes do cinema, a literatura já alimentava o olhar do leitor com inúmeras obras tematizando a criação. No Ocidente, além dos textos genesíacos dos gregos, da Bíblia e da Torah, as figuras de sereias, golens, ciclopes, centauros e górgonas recolocam o tema da criação de seres híbridos que, de certa forma, questionam a imagem puramente humana e, portanto, lembram a possibilidade de seu desaparecimento. Um dos exemplos mais interessantes a esse respeito talvez seja o de Pigmalião que burila uma estátua feminina, consegue animá-la e com ela se une.

Essas questões apontam como as musas da tradição inspiram uma determinada literatura coetânea, marcada por um olhar expectante frente ao poder da criação. Talvez a reverência prestada a certos mitos sobre a origem do mundo e dos homens seja uma das razões pelas quais alguns textos de Jorge Luis Borges, Adolfo Bioy-Casares e Ricardo Piglia fascinem o leitor da atualidade. Ao recontarem, de forma crítica e desencantada, ficções já internalizadas e recicladas ao longo dos séculos por gerações sucessivas de narradores, esses autores oferecem ao olhar contemporâneo algo que vagueia entre o arquetípico e o novo, o familiar e o estranho. Por outro lado, num contexto em que a "vontade de tudo ver" estimula "uma outra versão científica do olho de Deus", ${ }^{2}$ os textos que narram processos de criação trabalham com realidades simuladas, imagens virtuais que exacerbam a transparência e criam a ilusão de que nada mais há para ser visto e imaginado. Nesse rumo, se a clarividência atua como uma proibição ao segredo e à sombra, a arte apreendida pela visão, no cinema e na literatura, pode propor um percurso diferente: ao tematizar esse olhar que tudo vê, reserva-lhe surpresas e casualidades que embaraçam sua extrema visibilidade, reduzem sua onipotência e cavam espaços para a singularidade, a fantasia e a sabedoria cega que vê mais longe.

Um exemplo disso é o conto "As ruínas circulares", de Borges, ${ }^{3}$ onde um forasteiro impõe-se a tarefa de gerar um filho através de imagens oníricas. Aspectos que remontam a um sagrado arcaico - como os templos

2. VIRILO, 1994.

3. BORGES, 1989. As ruinos circulores. 
e deuses primitivos e destruídos, o nicho onde o mago se recolhe, os rituais de purificação - compóem um cenário propício ao sortilégio de uma criação que se realiza por meio de imagens vistas durante o sono. Nesse caso, o olhar do sonhador é responsável pelo engendramento de um corpo etéreo, cuja paulatina existência vai exaurindo a memória e a identidade paternas. O deus Fogo, ao animar a criatura, simultaneamente revela a base ilusória da identidade de pai e filho. Enquanto demiurgo, esse deus sofre a supressão de sua principal característica - a propriedade de provocar a combustão de outros corpos - e condena seus sacerdotes à eternidade fantasmagórica de simulacros do homem. Como um novo Lúcifer, esse portador de uma luz que queima sem consumir, frustra o desejo de humanidade do mago, ao lhe negar a condição de ser descontínuo e obrigálo a participar de uma absurda genealogia em que o esforço criativo redunda na imagem do Mesmo. O olhar do pai, ao perceber-se como uma citação de outro sonhador, perde o lugar sagrado da autoria e se compreende também como obra reduplicável, num processo circular de multiplicação de identidades em ruínas.

Essa sensação de irrealidade e simulação também se apresenta no texto $A$ invenção de Morel, de Adolfo Bioy-Casares. ${ }^{4}$ Enquanto "imaginação raciocinada", segundo o prefácio de Borges, a novela trabalha com elementos sugeridos pela tecnologia e pela mídia atuais, lembrando às vezes os percursos da fição científica. Ao relatar a morte gradual de personagens transformadas em realidades virtuais, a narrativa apresenta uma superposição de imagens, onde o olhar solitário de um náufrago contempla o fantasma de uma mulher que, por sua vez, contempla a imagem do pôr-do-sol. Olhares vazios e crepusculares, que nunca se cruzam, observam um mundo que já morreu e estranhamente ainda vive. A repetição sistemática de cenas e diálogos sinaliza a atuação vigilante e punitiva do olhar de uma câmera que fabrica fantasmas aos quais garante a imortalidade. Ao sequestrar a memória e a identidade das personagens, a máquina lhes impōe um presente sem datas, ao qual também convoca o olhar do fugitivo. Apaixonado por uma imagem de mulher que já morreu e para a qual ele nunca existiu, o expectador decide transformar-se em ator e penetrar na realidade simulada. Esse gesto suicida revela o paradoxo de um sujeito que se perde enquanto simulacro de si mesmo para adquirir uma imutável e eterna identidade. Expôr-se à visão homicida de uma máquina é a sentença que lhe cabe por querer tornar-se visível para Faustine, em cuja consciência não perde a esperança de introduzir-se.
O escritor Ricardo Piglia, em $A$ cidade ausente, ${ }^{5}$ também arquiteta uma imagem de mulher amada que se confunde com uma máquina literária. Elena constitui um artefato complexo, de identidade incerta, que reúne os atributos de psicótica, espiã, tradutora, rebelde, escritora, policial. Personagem multifacetada, desdobra-se em uma máquina de compilação de relatos alheios além de, na clínica, sentir-se incorporada a um aparelho que transforma seus pensamentos em imagens e os projeta na tela. A perda de qualquer privacidade e os sentimentos persecutórios daí decorrentes transformam Elena numa espécie de andróide que delira restos de uma linguagem e de um passado perdidos. Além dela, as outras personagens são também elementos indefinidos, que transitam entre homem e robô, cientista e louco, psicótico e viciado, cuja memória constitui uma cidade interna sempre destruída e refeita.

Nesse caso, o doutor Arana lembra o trabalho dos aracnídeos ao tramar as teias de outra identidade que, embora frágeis, são elásticas e poderosas o suficiente para capturar, controlar e perverter os que são considerados inssurrectos. A cura por ele proporcionada significa a implantação de uma memória artificial, através de intervenção cirúrgica nos nódulos brancos, considerados como regióes em que os códigos genético e verbal se condensam. $O$ processo de criação relatado em $A$ cidade ausente passa, ainda, por um mito de origem em que "uma linguagem cega" estaria outrora inscrita nos ossos de todos os seres vivos e cuja única pista mantinha-se no casco das tartarugas.

Atribuir a uma língua primordial a característica da cegueira significa um movimento paradoxal, já que à mesma é também conferido um sentido pleno. Para a personagem Grete, os nódulos brancos gravados no corpo teriam permitido um idioma comum, a compreensão de todos os significados e, portanto, a transparência da comunicação. A perda dessa memória coletiva - que parece ser o móvel das rebeliôes e perseguições dentro da narrativa - é intensificada por cirurgias e operações de vigilância realizadas por câmeras de vídeo em circuitos fechados. O pensamento deixa de ser uma linguagem muda, íntima, privada e, através de projeções em telas públicas ou por processos telepáticos, passa a ser controlado pelo olhar do outro. Assim, se no mito grego Helena se encontra numa cidade sitiada, na ficção contemporânea outra Elena padece de um cerco interno, por meio do qual é a própria memória que se torna prisioneira.

Resíduos do passado, frágeis desejos pessoais e imaginação 
Disponível em http://www.letras.ufmg.br/poslit

enlouquecida alimentam, em Elena-máquina, uma sucessão desconexa de imagens puramente virtuais. Contudo, à medida que funciona, esse artefato humano projeta realidades imaginadas e as transforma em realidades sensíveis, expostas no Museu, e referentes a um passado inexistente ou hipotético. Nesse real absurdo, fiç̧ão e vida inventam-se mutuamente, numa singular conexão de lembranças e esquecimentos que condensam e dispersam imagens da tradição literária, das personagens, da história latinoamericana.

Enquanto artifício que norteia a invenção do romance, em suas alucinações, Elena homenageia os escritores argentinos Macedonio Fernández e Jorge Luis Borges ao mesmo tempo em que mistura certas personagens masculinas: Luca Lombardo, o Italiano, é por ela chamado de "Mac" numa possível alusão às iniciais do nome de Macedonio, o homem que, por muito amá-la, garantiu sua imortalidade transformandoa numa máquina multiplicadora de textos. Num episódio entre a personagem Mac - um Macedonio idoso - e o Italiano, ambos estão envolvidos com microprocessadores clandestinos e TVs microscópicas que só sintonizam canais do passado, aparelhos que recordam a tela minúscula do Aleph, de Borges. Outras analogias podem ser localizadas dentro da trama: tanto as intervenções de doutor Arana nos nódulos brancos quanto à máquina-escritora de Macedonio alteram a memória coletiva e/ou pessoal, provocando o apagamento da aura da liberdade individual, do saber coerente, da verdade científica, da tradição nacional - idéias caras ao olhar iluminista da Modernidade. Além disso, alguns elementos de uma urbis enlouquecida - como os corpos metálicos e transparentes, o movimento caótico, a ausência de projetos históricos, a espreita mútua das personagens — vão compondo um cenário de riscos, desordem, caos. Se nesse contexto é possível a existência de uma história de amor, ela resulta em desgraça. Como em vários outros mitos de fundação, o afeto de Macedonio por Elena transforma sua vida numa imortal agonia, presidida pelo medo de ser desativada, desgravada, invadida. Impotente diante do escritor ou do psiquiatra, a personagem rasteja no subsolo do metrô, deambula pela clínica, pisca imóvel no centro do Museu. Enquanto heroína da atualidade, sua única saída é trocar de alucinações, deturpar histórias, usar a memória alheia como uma forma de resistir à morte e ao silêncio. Ser "eterna e infeliz" configura-se como o destino reservado a essa personagem de tragédia contemporânea.

Nessa narrativa encontramos, portanto, a tematização de uma sociedade paranóica. Invadida pelas "máquinas de visão" mencionadas por Virilio - como os arsenais de dissimulação e dissuasão que registram e gerenciam dados estratégicos de uma guerra de imagens - ou por inúmeras telas de controle em locais públicos e privados, a sociedade contemporânea organiza-se através de um olhar vigilante. A insônia do corpo social responsável pela multiplicação de sua insânia. Num estado constante de alerta, sendo ao mesmo tempo o que observa e é observado, o sujeito transforma seu olhar em projétil e alvo, em linguagem defensiva e imperativa, cautelosa e turbulenta.

Nessa realidade simulada, onde as imagens virtuais tornam cada vez mais tênues os limites entre fiç̧ão e realidade, um olhar que nunca dorme é obrigado a deslocar-se incessantemente na tentativa de apreender e construir objetos fugazes, descartáveis. É a solicitação ininterrupta de um real heterogêneo e ficcionalizado que abre espaço para o estrabismo crítico proposto por Ricardo Piglia. Mirar diferentes imagens ao mesmo tempo torna-se um pressuposto necessário à existência dos homens e de sua literatura, inclusive porque o objeto da visão nunca existe em estado puro e acabado. Pelo contrário, ele é sempre reinventado pela mirada estrábica que o confronta com outros objetos, que o busca onde não poderia ser esperado, que não o percebe por estar muito visível.

A miopia de certas personagens de $A$ cidade ausente, como Júnior e Mac, sinaliza ainda outra perspectiva na qual o segredo está na superfície mas imperceptível devido à distância do observador. A dificuldade para ver de longe parece estar presente na tarefa de recontar antigas histórias: apropriar-se de seus núcleos narrativos, como o faz a máquina-escritora, estabelece uma dinâmica de resistência ao desaparecimento da tradição, por sua renovação através da contrafação textual e de uma incerta identidade. Na América Latina contemporânea, um olhar defeituoso cego, míope, estrábico - extrai de uma memória cultural heterogênea e de um presente imagético os elementos com os quais fabrica essa ilusão de ótica chamada ficção.

Talvez se possa dizer que esse olhar trabalha como o rabino do poema "El Golem",' de Borges:

Sediento de saber lo que Dios sabe,

Judá León se dio a permutaciones

De letras y a complejas variaciones

Diante da infinita possibilidade de criação de sentidos, inventamse imagens heteróclitas, às vezes monstruosas, contempladas pelo leitor

6. BORGES. EI Golem. In: MONEGAL, 1985.1011 
"con ternura y con algún horror", já que às mesmas ele se identifica porque nelas reconhece uma memória coletiva latino-americana. Ao configurar uma versão apócrifa da criação de Adão, o Golem também propõe ao leitor experimentar um outro espaço de identificação, onde a multiplicidade dos arquétipos desconstrói os lugares fixos da tradição e, por isso mesmo, viabiliza sua releitura e permanência. Assim, a diversidade da genealogia proporciona uma visão fantasmática da origem histórico-adâmica e da própria identidade civil. Pertencer a uma linhagem onde imperam a diferença e a mutação torna o leitor um filho de simulacros, também ele sonhado através de imagens cabalísticas e multiplicador de criaturas quase sempre rebeladas contra o criador. Nesse sentido, a dinâmica da invenção desencadeia surpreendentes conseqüências como a expulsão do paraíso, a transfiguração da memória, o rompimento de selos: algo que, para render frutos, hesita entre os signos emet - "verdade" - emet - "morte" - e sabe que o apagamento de uma letra pode mudar o destino do olhar e do texto, da leitura, do mundo.

\section{REFERÊNCIAS BIBLIOGRÉFICAS}

BIOY-CASARES, A. A invenç̃õo de Morel. Rio de Joneiro: Rocco, 1986

BORGES I L Fic A Rin

MONEGAL, E. R. J. L. Borges. Ficcionario - uno antalogia de sus textos. Mexica: Fondo de Cultura Económica, 1985.

.

. 